\title{
The prevention and control of feather pecking in laying hens: identifying the underlying principles
}

T.B. RODENBURG ${ }^{1,2}$, M.M. VAN KRIMPEN ${ }^{3}$, I.C. DE JONG ${ }^{3}$, E.N. DE HAAS ${ }^{4}$, M.S. KOPS ${ }^{5}$, B.J. RIEDSTRA ${ }^{6}$, R.E. NORDQUIST ${ }^{7}$, J.P. WAGENAAR ${ }^{8}$, M. BESTMAN ${ }^{8}$ and C.J. NICOL ${ }^{9}$

${ }^{1}$ Animal Breeding and Genomics Centre, Wageningen University, PO Box 338, 6700 AH Wageningen, The Netherlands; ${ }^{2}$ Behavioural Ecology Group, Wageningen University, PO Box 338, 6700 AH Wageningen, The Netherlands; ${ }^{3}$ Livestock Research, Wageningen UR, PO Box 65, 8200 AB, Lelystad, The Netherlands; ${ }^{4}$ Adaptation Physiology Group, Wageningen University, PO Box 338, $6700 \mathrm{AH}$ Wageningen, The Netherlands; ${ }^{5}$ Department of Psychopharmacology, Utrecht Institute for Pharmaceutical Sciences (UIPS) and Rudolf Magnus Institute of Neuroscience, Utrecht University, PO Box 80.082, 3508 TB Utrecht, The Netherlands; ' ${ }^{6}$ Behavioural Biology, University of Groningen, Nijenborgh 7, 9747 AG Groningen, The Netherlands; ${ }^{7}$ Emotion \& Cognition Group, Department of Farm Animal Health, Faculty of Veterinary Medicine and Rudolf Magnus Institute of Neuroscience, Utrecht University, Yalelaan 7, 3584 CL Utrecht, The Netherlands; ${ }^{8}$ Louis Bolk Institute, Hoofdstraat 24, 3972 LA Driebergen, The Netherlands;

${ }^{9}$ Animal Welfare \& Behaviour, School of Veterinary Sciences, Bristol University, Langford House, Langford, Bristol, BS40 5DU, United Kingdom

*Corresponding author: bas.rodenburg@wur.nl

Feather pecking (FP) in laying hens remains an important economic and welfare issue. This paper reviews the literature on causes of FP in laying hens. With the ban on conventional cages in the EU from 2012 and the expected future ban on beak trimming in many European countries, addressing this welfare issue has become more pressing than ever. The aim of this review paper is to provide a detailed overview of underlying principles of FP. FP is affected by many different factors and any approach to prevent or reduce FP in commercial flocks should acknowledge that fact and use a multifactorial approach to address this issue. Two forms of FP can be distinguished: gentle FP and severe FP. Severe FP causes the most welfare issues in commercial flocks. Severe FP is clearly related to feeding and foraging behaviour and its development seems to be enhanced in conditions where birds have difficulty in coping with environmental stressors. Stimulating feeding and foraging behaviour by providing high-fibre diets and suitable litter from an early age onwards, and controlling fear and stress levels 
through genetic selection, reducing maternal stress and improving the stockmanship skills of the farmer, together offer the best prospect for preventing or controlling FP.

Keywords: laying hen; feather pecking; ontogeny; fearfulness; environmental enrichment; foraging

\section{Introduction}

Feather pecking (FP), i.e. the pecking, pulling out and eating of feathers of conspecifics, remains an important welfare issue in laying hens. With the ban on conventional cages in the EU from 2012 following Council Directive 1999/74/EU and the expected future ban on beak trimming in many European countries in the future (Van Horne and Achterbosch, 2008), addressing this welfare issue has become more pressing than ever. In large group housing systems, such as large furnished cages but especially non-cage systems, FP is much more difficult to control than in conventional cages (Rodenburg et al., 2012). It is challenging to identify and remove the feather peckers in these systems and feather peckers have many more potential victims compared with cage systems. Also FP may spread through the flock by social transmission. The aim of this review paper is to provide a detailed analysis of the underlying principles of FP. We shall describe different forms of FP and their causes. Then we shall move to the relationships between FP, feeding and foraging behaviour and describe the link with dietary aspects. Further, we will explore the role of the parental environment and its effect on maternal hormones. Finally, we shall focus on the role of individual behavioural characteristics and the relationship between the ability to cope with fear and stress and the development of FP. Taken together, this enables us to formulate promising strategies to reduce FP in commercial flocks of laying hens.

\section{Forms of feather pecking}

Two different forms of FP can be distinguished: gentle and severe FP (Savory, 1995). Gentle FP (GFP) consists of gentle pecks to the tips of the feathers. This type of FP usually does not result in much damage and is generally ignored by the recipient, although stereotyped gentle FP can indicate a welfare problem in the bird performing the behaviour. Severe FP (SFP) is the most problematic type of FP in terms of damage to the recipient. It consists of forceful pecks and pulls of feathers that are frequently eaten and results in feather loss on the back, vent and tail area. Victims of SFP often initially show a behavioural response to receiving SFP, either by moving away or by confronting the pecker. If SFP continues, however, victims have also been observed to surrender to being pecked and remain still. SFP results in damage to the feathers and feather loss which leads to bald patches and can be followed by tissue pecking, a form of cannibalistic pecking where pecking continues on the skin, leading to wounds. Tissue pecking can eventually lead to the victim's death due to excessive blood loss and tissue damage. A separate form of cannibalistic pecking is vent pecking, where the pecker pecks at the vent of the victim and may pull out the inner organs. This type of cannibalistic pecking can also develop in well-feathered birds and is sometimes seen around the onset of egg laying (Newberry, 2004). Cannibalistic pecking can also be observed in the form of toe pecking (Glatz and Bourke, 2006; Rodenburg et al., 2009b). There is some evidence that victims of FP are also more likely to receive high levels of 
toe pecking (Leonard et al., 1995). Aggressive pecking is a separate form of bird-to-bird pecking which, together with threatening behaviour, is used to establish and maintain dyadic relationships between birds, resulting in a stable dominance hierarchy. Aggressive pecks are forceful pecks directed at the head or neck of the recipient, but usually these pecks do not result in much feather damage (Savory, 1995). FP is not a form of aggressive behaviour.

An important issue in FP research is to determine whether GFP can develop into SFP, in other words: is GFP a predictor or a precursor of the more damaging SFP? Most studies that have investigated this relationship would say that it is not (Rodenburg et al., 2004b; Lambton et al., 2007; Newberry et al., 2007; Hughes and Buitenhuis, 2010). Rodenburg et al. (2004b) showed that although the vast majority of birds showed GFP at six weeks of age, only $2 \%$ showed SFP. At 30 weeks of age SFP was observed in $15 \%$ of the birds. No evidence was found that GFP developed into SFP, although correlations were found between GFP and SFP at the same age (birds performing SFP would also show GFP). Similar results were found by Newberry et al. (2007), who further distinguished between exploratory GFP and stereotyped GFP. They found that SFP in adult birds was correlated with foraging and exploratory pecking when these same birds were young, but not with stereotyped GFP. Indeed, Lambton et al. (2007) studied the relationship between GFP and SFP in commercial flocks and found no evidence that high levels of GFP would lead to high levels of SFP. This is confirmed by a gene expression study by Hughes and Buitenhuis (2010), showing that GFP and SFP have distinct gene expression patterns. Conversely, Chow and Hogan (2005) suggested that GFP could develop into SFP, based on the observation that GFP decreased and SFP increased over time. This relationship was, however, not confirmed by correlating GFP in young birds and SFP in these same birds when adult. The distinction between GFP and SFP has not always been made in earlier studies.

\section{Causes of feather pecking and the importance of litter}

There are several theories about causes of FP behaviour. Vestergaard and Lisborg (1993) hypothesised that FP is related to pecking during dustbathing. They found that birds that were reared with substrates that are unsuitable for dustbathing, such as feathers, showed more FP. However, Blokhuis (1989) proposed that FP is more likely to be a form of redirected ground pecking behaviour, derived from foraging. He showed that laying hens will develop FP in the absence of a suitable foraging substrate. In line with his observations, Huber-Eicher and Wechsler (1997) found that access to straw, a foraging substrate, did decrease FP, but access to sand, a dustbathing substrate, did not or only to a limited extent. This is supported by a study showing that peat in early rearing (that is preferred for dustbathing but not for foraging) did not reduce early FP behaviour (Dixon and Duncan, 2010). In a study by Johnsen et al.(1998), pullets were raised on sand, straw, or wire between 0-4 weeks of age. Thereafter all groups were kept on sand and straw. Hens raised on wire had the poorest plumage condition, showed more FP, had a lower dustbathing activity, and had higher mortality rates due to cannibalism, compared to hens on litter. This may indicate that the first four weeks of life have a large influence on the development in FP behaviour. This could however not be confirmed by Nicol et al. (2001). In their study, birds were kept on wire floors, and, at different ages, wire was replaced by solid floors with wood shavings. Adult hens kept on wire floors during their entire life, showed more SFP compared to hens kept on floors with wood shavings. However, this study also showed that current substrate exposure played a major role: regardless of previous 
experience, birds housed on shavings even later in rearing showed less FP and more foraging compared with birds housed on wire (Nicol et al., 2001). Huber-Eicher and Wechsler (1997) further showed that age of exposure seemed to influence SFP rates. Pullets that had access to litter from the age of 10 days showed more FP, compared to pullets that had access to litter from one day after hatching. The importance of litter in early rearing was further studied in two experiments by De Jong et al. (2013). In the first experiment birds were housed on litter (wood shavings or sand) during the entire experiment, or on mesh matting or chick paper for the first three weeks and provided with either wood shavings or sand thereafter. Results showed that providing chicks with litter increased foraging and reduced FP until four weeks of age, but not after this time. It was suggested that, in line with Nicol et al. (2001), adult behaviour seemed to be strongly determined by the current substrate (De Jong et al., 2013). In a second experiment, chicks were reared on mesh matting or wood shavings during the first three weeks of life, and thereafter both treatments received wood shavings. Frequency of SFP was low in both treatments, but birds reared on mesh did show more SFP at four and eight weeks of age, and more GFP as adults than birds reared on wood shavings (De Jong et al., submitted). This indicates that early experience with substrate has a longlasting effect on pecking behaviour. Blokhuis and Van Der Haar (1992) showed that supplying grain in the litter could be used to further stimulate foraging and reduce FP. Other devices such as bunches of white string, that encourage environmental pecking, also have been used successfully to reduce FP (McAdie et al., 2005), confirming the link between FP and exploratory behaviour. These studies confirm that early access to litter for foraging, preferably straw or wood shavings, is an important factor in the reduction of FP. This approach could be combined with supplying grain in the litter or other pecking devices.

\section{Individual variation in foraging behaviour}

Apart from environmental factors, such as litter supply, variation in foraging behaviour will affect the risk of FP. Newberry et al. (2007) confirmed that birds that exhibited more foraging as chicks, were more likely to develop SFP as adults. However, they also showed that FP did not replace ground pecking behaviour: feather peckers continued to show high levels of ground pecking in their study. Line differences in foraging behaviour have also been found between lines characterised as high or low FP: birds from a low FP line spent more time on foraging and feeding behaviour and showed less (gentle) FP behaviour compared to a high FP line (Van Hierden et al., 2002a; Rodenburg and Koene, 2003). Low FP birds may be less likely to redirect their pecks to the feathers of conspecifics. If FP is related to foraging motivation, then the provision of a suitable litter substrate should facilitate more normal foraging behaviour and discourage FP; and this is generally found to be the case. In the absence of litter, more FP occurs, although availability of litter will not eliminate FP completely (Blokhuis and Van Der Haar, 1992; Nicol et al., 2001). When developing strategies to reduce FP, individual and strain differences in pecking motivation and in the risk of redirecting foraging pecks to feathers of conspecifics need to be taken into account.

\section{Motivational background of gentle and severe FP}

GFP and SFP each seem to have their own motivational background. GFP has also been suggested to be a form of social exploration, with pecks frequently directed at unfamiliar 
individuals (Riedstra and Groothuis, 2002). This may partially explain why GFP is seen more frequently in young birds, where social relationships still have to be established, compared to adult birds (Chow and Hogan, 2005). In adult birds, GFP can be observed as stereotyped GFP, for instance in the form of frequent pecks on the tips of the tail feathers. McAdie and Keeling (2002) suggested that stereotyped GFP may develop from normal GFP as observed in young birds. However, Newberry et al. (2007) found no indications for this relationship, rather birds showing stereotyped GFP when adult were more likely to have displayed the same behaviour when young. SFP has been related to a range of dietary factors. It is certainly associated with feather eating (McKeegan and Savory, 1999; Ramadan and Von Borell, 2008; Harlander-Matauschek and Häusler, 2009). McKeegan and Savory (1999) showed that groups of hens with high levels of FP had fewer feathers on the floor. Indeed Ramadan and Von Borell (2008) found that removing loose feathers from the litter during rearing, and hence avoiding the development of feather eating, reduced FP during the laying period, thus confirming the relationship between SFP and feeding. If hens learn to eat feathers from the floor, it is possible that they will redirect this behaviour towards conspecifics when feathers on the floor are no longer present. A joint cause of SFP and feather eating may be the relatively low fibre content of most commercial laying hen diets. The different motivational background of GFP and SFP underlines the importance to distinguish between both behaviours.

\section{Impact of dietary factors}

Diet composition is known to influence FP behaviour. Protein, minerals, energy, and fibre levels can affect SFP (Van Krimpen et al., 2005). Evidence was found in the literature that a dietary deficiency of crude protein (Ambrosen and Petersen, 1997), and, more specifically, of the amino acids lysine (Al Bustany and Elwinger, 1987a; 1987b) and methionine + cysteine (Elwinger et al., 2002) increased SFP behaviour, as indicated by a poorer plumage condition. SFP increased when levels of crude protein, lysine or methionine + cysteine were reduced below $125,8.2$ and $5.1 \mathrm{~g} / \mathrm{kg}$, respectively. Dietary recommendations to realise maximal egg performances for these nutrients are $150,6.9$, and $5.8 \mathrm{~g} / \mathrm{kg}$, respectively (NRC, 1994), indicating that SFP is not expected to increase if the diets fulfil the standard crude protein and methionine + cysteine requirements. The desired dietary lysine content for realising optimal plumage condition, however, is higher than the lysine content required for maximal egg performances. Likewise, SFP increased in case of dietary deficiencies of magnesium (about $0 \mathrm{~g} / \mathrm{kg}$, whereas $0.5 \mathrm{~g} / \mathrm{kg}$ is recommended) (Schaible et al., 1947), sink $(<10$ ppm, whereas $40 \mathrm{ppm}$ is recommended) (Sunde, 1972), and sodium $(<0.3 \mathrm{~g} / \mathrm{kg}$, whereas $1.5 \mathrm{~g} / \mathrm{kg}$ is recommended) (Hughes and Whitehead, 1974). This shows that dietary factors play an important role in the risk of FP.

\section{Dilution of the diet and high fibre diets}

Reduced energy levels in the feed can improve plumage condition (Van Der Lee et al., 2001). This can be realised by diluting the diet, for instance by adding insoluble fibre. Dilution of the diet, leading to reduced energy content, led to increased feeding time in Japanese quail (Savory, 1980). This could result in decreased time spent on SFP, as this problem is related to feeding behaviour. In hens, it has been suggested that increasing the dietary fibre content above $80 \mathrm{~g} / \mathrm{kg}$ could result in reduced FP occurrences and improved plumage (Esmail, 1997). Insoluble fibres, such as non-starch polysaccharides (NSP's), are 
especially effective in increasing eating time in laying hens (Van Krimpen et al., 2007). Fibre may have positive effects on gut motility and satiety. Due to the accumulation of fibre in the gizzard, the passage rate of the digesta through the gizzard was reduced when increased levels of coarse fibre were included in the diet, which may increase the feeling of satiety in the bird and reduce the propensity to peck and eat feathers of conspecifics (Hetland et al., 2004; Van Krimpen et al., 2011). Harlander et al. (2007) compared feather eating behaviour in birds selected for high and low FP and found that high FP birds were more motivated to eat feathers. They also showed that feathers had a positive effect on gut motility, which may be similar to the effect of NSP's (HarlanderMatauschek et al., 2006), illustrating that hens may indeed eat feathers to increase satiety. The effects of feeding low energy diets or high NSP diets during the rearing and laying period were studied by Van Krimpen et al. (2009). Pullets that were fed low energy diets compensated for the level of nutrient dilution by a proportionally increased feed intake. In contrast to findings in adult laying hens, they increased their eating rate, without increasing eating time. Nevertheless, reduced energy levels during the rearing period reduced SFP behaviour during the laying period, indicating that the increased focus on feed in the rearing period reduced the preference for feathers of conspecifics during the laying period. Providing high insoluble NSP diets during the laying period, however, resulted in less feather damage compared to the hens that were given standard non-diluted diets. The positive effects of feeding NSP diluted diets on feather damage during the laying period were greatest if these diets were provided during both the rearing and laying period, rather than only during the rearing or the laying period (Van Krimpen et al., 2010). A daily insoluble NSP intake of at least $10 \mathrm{~g} / \mathrm{pullet} / \mathrm{d}$ during the rearing period and $16 \mathrm{~g} / \mathrm{hen} / \mathrm{d}$ during the laying period was found to minimise the risk of SFP behaviour (Van Krimpen et al., 2009; Van Krimpen et al., 2012). Dietary factors that increase the time spent on feeding-related behaviour and induce satiety can be expected to reduce FP in rearing and laying hens. This is underlined by the finding by Webster (1995) that fasting indeed led to an increase in FP behaviour. Taken together these results indicate that dilution of the diet and feeding high fibre diets are promising routes to reduce SFP.

\section{The role of maternal hormones}

Apart from environmental effects, other factors also play a role in the behavioural development of the chick and the risk of developing FP. The avian egg yolk is the main source of nutrients for the developing chick embryo, and contains significant quantities of steroid hormones, such as oestrogens and androgens. These steroid hormones can have long lasting organising effects on the brain and behaviour of individuals (Schwabl, 1993; Von Engelhardt and Groothuis, 2011). The deposition of hormones in the yolk is a mechanism by which the mother can adjust the development of her offspring to the prevailing environmental conditions (Groothuis et al., 2005). There are several reasons why studying hormone-mediated maternal effects is important for understanding FP (and behavioural pathologies in general): Firstly, laying hen parent stock is frequently housed in large flocks and thus birds encounter many conspecifics. Social interactions, such as aggressive challenges, stimulate androgen production, whereas both social and non-social challenges, such as stressful events in the environment, may influence glucocorticoid levels in the mother. Both experimental and correlational evidence shows that social factors such as social density can be reflected in the hormone content of the eggs (see Groothuis et al., 2005). There may therefore be an association between the hormonal balance of the mothers and 
development of FP in their offspring. Indeed, Hughes (1973) found that the amount of FP and cannibalism could be reduced by administering testosterone to pullets. El-lethey et al. (2001) showed that feeding young laying hens corticosterone led to reduced growth, increased flightiness and increased FP later in life. Janczak et al. (2007) found that chicks from a stressed mother, with elevated faecal corticosterone levels, were more fearful and less competitive than chicks from a non-stressed mother. Similar effects were found when eggs were treated with corticosterone (Freire et al., 2006), indicating that indeed maternal stress translates to the offspring.

Secondly, there may be a mismatch between the environment in which the parental strains produce the fertile eggs containing the next generation and the environment in which the layer chick, and later hen, is reared and kept to produce consumer eggs. The most obvious difference is the presence of males in the parental generation and their absence in the laying hen flock. In addition the housing system can be quite different (for instance floor housing versus aviary housing). If indeed hormonal deposition in the yolk is adaptively tuned to the maternal environment (Groothuis et al., 2005), then the laying hen flock may not be optimally adapted to their living environment. Thus the hormonal balance of the egg is a possible predictor for the development of later pathological behaviour. Studies are needed in commercial flocks, investigating the relationship between stress in the parent stock, the hormonal contents of their eggs and the behavioural development of their offspring. If such a relationship can be confirmed, reducing stress in parent stock flocks, for instance by lowering stocking density or group size, or creating a better match between parent stock and laying hen housing could be a viable way to reduce FP.

\section{Behavioural traits and coping with fear and stress}

Behavioural characteristics of individual birds, such as fearfulness and social motivation, also play a role in the development of FP. Fearfulness is an individual's likelihood of being easily frightened (Jones, 1996). Associations between fearfulness and FP or feather damage have been found (Hughes and Duncan, 1972; Jones et al., 1995; Rodenburg et al., 2004a). While fear can be increased due to FP (Blokhuis and Beutler, 1992; Vestergaard et al., 1993), increased fearfulness can also be a predictor for the development of FP. Rodenburg et al. (2004a) found that fearful chicks in an open field (OF) test (as indicated by a long duration of freezing) showed more GFP and SFP as adults. Similarly, Jones et al. (1995) found that chicks from a high FP line were more fearful in an OF test (longer latency to vocalize and walk) than chicks from a low FP line. In a commercial line selected on reduced group mortality due to FP (Ellen et al., 2007), six-week old chicks showed less fear in an OF test in comparison to a nongroup selected control line (Rodenburg et al., 2009b). Fear responses may differ between young and adult hens (Hocking et al., 2001). In adult hens, high activity in an OF has been associated with FP in various genetic lines and crosses (Rodenburg et al., 2004a; Jensen et al., 2005; De Haas et al., 2010). Positive associations have been found between the duration of TI (as measure of fearfulness) and GFP and between TI and feather damage (Blokhuis and Beutler, 1992), where birds with a longer duration of TI had more damage. Similarly, Campo et al. (2008) reported a longer TI duration in victims of vent pecking. When comparing commercial lines, hens from a white breed origin had a longer TI duration at 13 weeks of age (Albentosa et al., 2003) and 44 weeks of age (Mahboub et al., 2004) compared to hens from a brown breed origin. Uitdehaag et al. (2008a) found hens from a white breed origin to be more flighty and to show more FP than hens from a brown breed origin. They performed multiple studies with purebred genetic selection 
lines from a White Leghorn (WL) and Rhode Island Red (RIR) origin (Uitdehaag et al., 2008a; 2008b; 2009). RIR hens were less likely to withdraw from a novel object and had less feather damage than WL hens. For both WL and RIR lines a positive association between response to the novel object and feather damage at a later age was found (Uitdehaag et al., 2008b). Rodenburg et al. (2010) performed the same test with hens selected for high FP and low FP birds at 30 weeks of age, but did not find differences in fear response between the lines. For both lines however, increased levels of feather damage were associated with a withdrawal response to the novel object.

Additional physiological information may help in understanding the total concept of how an animal's ability to cope with fear and stress may influence FP (Korte, 2001). For example, restraining birds for a predetermined time is known to induce a physiological stress response by increasing corticosterone levels. Hens of a second generation groupselected for low mortality due to FP had lower corticosterone levels post-restraint (Rodenburg et al., 2009a), struggled more and had higher whole-blood serotonin levels compared to non-selected controls (Bolhuis et al., 2009). Similarly, high FP hens (selected directly for high FP behaviour (Kjaer et al., 2001)) showed higher corticosterone (Kjaer and Guémené, 2009) and a higher heart rate with lower heart rate variability in response to restraint (Kjaer and Jorgensen, 2011) compared to low FP hens. In lines which coincidentally differed in FP, high FP hens also had a higher heart rate with lower heart rate variability in response to physical restraint (Korte et al., 1999). Birds from the high FP line in this study, however, had lower corticosterone levels than birds from the low FP line, both basal and in response to restraint (Korte et al., 1997). Hens originating from lines which have a higher propensity to develop FP seem to be more sensitive to stress-eliciting situations. However, we should be aware that the environment, especially the rearing environment (Rodenburg et al., 2008) and possible genotype by environment interactions may cause discrepancies between different genetic lines of laying hens.

It has been proposed that individual variation in the predisposition to develop SFP is associated with differences in serotonergic neurotransmission in the brain (Van Hierden et al., 2002b; 2004a). Distribution of serotonergic fibres in the chicken brain (Metzger et al., 2002) suggests an important role for serotonin in fear-related and social behaviour (Gruss and Braun, 1997). Acute reduction of serotonin turnover in the chicken forebrain resulted in increased GFP and SFP, whereas supplementation with L-tryptophan led to decreased GFP and a non-significant reduction in SFP (Van Hierden et al., 2004b), indicating that the display of FP may be related to low serotonin neurotransmission. In line with this, brain serotonin turnover in young chicks from a high FP line was lower compared to chicks from a low FP line (Van Hierden et al., 2002b). Furthermore, dopaminergic neurotransmission may play a role in FP, as FP has been reported to decrease following injection with the dopamine antagonist haloperidol (Kjaer et al., 2004). Chicks from a high and low FP line differed in dopamine turnover (Van Hierden et al., 2002b) and in sensitivity for the dopamine-agonist apomorphine (Van Hierden et al., 2005). These studies indicate that there is scope for genetic selection for birds that have an improved ability to cope with fear and stress and, as a result, show reduced levels of FP.

\section{Conclusions}

The aim of this review paper was to provide a detailed analysis of the underlying principles of FP. What we have shown is that FP is affected by many different factors and that any approach to prevent or reduce FP in commercial flocks should 
acknowledge this and apply a multifactorial approach to address the issue. A central and important factor remains stimulating feeding and foraging behaviour, either by nutritional approaches such as diluting the diet or supplying high-fibre diets, or by offering suitable litter preferably enriched with some feed ingredients (e.g. wheat or alfalfa) to stimulate foraging behaviour from an early age onwards. Focus is needed on early-life experiences, as it is clear that experiences with the absence or presence of litter during rearing has implications during later life. Based on what is known on the transmission of maternal stress to the offspring in birds, we need to investigate further how maternal stress affects behavioural development of the offspring and whether reducing maternal stress affects levels of FP. Clearly, differences in behavioural characteristics between birds from different genetic backgrounds should be taken into account, as there are clear differences in the ability to cope with fear and stress between different commercial hybrids. Recent selection experiments provide further evidence for the relationship between the ability to cope with fear and stress and the development of FP. Here, management plays a role as the level of fearfulness is related to the stockmanship of the farmer (Hemsworth and Barnett, 1989). In conclusion, based on what is known on causes of FP, an approach that addresses 1) the role of feeding and foraging behaviour in young and adult birds, 2) the parental environment and the role of maternal stress, and 3) the role fear and stress in the development of FP, provides the most scope for a sustainable solution to the issue of FP in laying hens.

\section{Acknowledgements}

Dr Liesbeth Bolhuis is gratefully acknowledged for commenting on a previous version of the manuscript. The authors would also like to thank the anonymous reviewer for his or her constructive comments on this review paper. This review is based on a symposium on feather pecking in laying hens held at Bristol University on 18 May 2011. This symposium was organised jointly by the University of Bristol and Wageningen University. The Dutch Research programme on feather pecking in laying hens is part of the NWO programme The Value of Animal Welfare, funded by The Netherlands Organization for Scientific Research (NWO), Division of Earth and Life Sciences (ALW) and the Dutch Ministry for Economic Affairs.

\section{References}

AL BUSTANY, Z. and ELWINGER, K. (1987a) Comparison between barley/fish meal- and maize/soybean meal-based diets with various lysine and protein levels fed to different strains of laying hens. Acta Agriculturae Scandinavica 37: 41-49.

AL BUSTANY, Z. and ELWINGER, K. (1987b) Response of laying hens to different dietary lysine intakes. A comparison of some commercial hybrids with strains selected on a low protein diet. Acta Agriculturae Scandinavica 37: 27-40.

ALBENTOSA, M.J., KJAER, J.B. and NICOL, C.J. (2003) Strain and age differences in behaviour, fear response and pecking tendency in laying hens. British Poultry Science 44: 333-344.

AMbrosen, T. and PETERSEN, V.E. (1997) The influence of protein level in the diet on cannibalism and quality of plumage of layers. Poultry Science 76: 559-563.

BLOKHUIS, H.J. (1989) The development and causation of feather pecking in the domestic fowl. - Vakgroep Ethologie, Thesis Landbouw Universiteit Wageningen, Wageningen.

BLOKHUIS, H.J. and BEUTLER, A. (1992) Feather pecking damage and tonic immobility response in two lines of white leghorn hens. Journal of Animal Science 70: 170.

BLOKHUIS, H.J. and VAN DER HAAR, J.W. (1992) Effects of pecking incentives during rearing on feather pecking of laying hens. British Poultry Science 33: 17-24. 
BOLHUIS, J.E., ELLEN, E.D., VAN REENEN, C.G., DE GROOT, J., TEN NAPEL, J., KOOPMANSCHAP, R., DE VRIES REILINGH, G., UITDEHAAG, K.A., KEMP, B. and RODENBURG, T.B. (2009) Effects of genetic group selection against mortality on behaviour and peripheral serotonin in domestic laying hens with trimmed and intact beaks. Physiology \& Behavior 97: 470-475.

CAMPO, J.L., PRIETO, M.T. and DÁVILA, S.G. (2008) Association between vent pecking and fluctuating asymmetry, heterophil to lymphocyte ratio, and tonic immobility duration in chickens. Applied Animal Behaviour Science 113: 87-97.

CHOW, A. and HOGAN, J.A. (2005) The development of feather pecking in Burmese red junglefowl: the influence of early experience with exploratory-rich environments. Applied Animal Behaviour Science 93: 283294.

DE HAAS, E.N., NIELSEN, B.L., BUITENHUIS, A.J. and RODENBURG, T.B. (2010) Selection on feather pecking affects response to novelty and foraging behaviour in laying hens. Applied Animal Behaviour Science 124: 90-96.

DE JONG, I.C., GUNNINK, H., ROMMERS, J.M. and BRACKE, M.B.M. (2013) Effect of substrate during early rearing on floor- and feather pecking behaviour in young and adult laying hens. Archiv fur Geflugelkunde 77: 15-22.

DE JONG, I.C., REUVEKAMP, B.M. and GUNNINK, H. (submitted) Exposure to substrate in early rearing and the development of (feather) pecking behaviour in laying hens.

DIXON, L.M. and DUNCAN, I.J.H. (2010) Changes in substrate access did not affect early feather-pecking behavior in two strains of laying hen chicks. Journal of Applied Animal Welfare Science 13: 1 - 14.

EL-LETHEY, H., JUNGI, T.W. and HUBER-EICHER, B. (2001) Effects of feeding corticosterone and housing conditions on feather pecking in laying hens (Gallus gallus domesticus). Physiology \& Behavior 73 : 243-251.

ELLEN, E.D., MUIR, W.M. and BIJMA, P. (2007) Genetic improvement of traits affected by interactions among individuals: sib selection schemes. Genetics 176: 489-499.

ELWINGER, K., TAUSON, R., TUFVESSON, M. and HARTMANN, C. (2002) Feeding of layers kept in an organic feed environment. 11th. European Poultry Conference, Bremen.

ESMAIL, S.H.M. (1997) Fibre nutrition. Poultry International 36: 31-34.

FREIRE, R., VAN DORT, S. and ROGERS, L.J. (2006) Pre- and post-hatching effects of corticosterone treatment on behavior of the domestic chick. Hormones and Behavior 49: 157-165.

GLATZ, P.C. and BOURKE, M. (2006) Chapter 1. Pecking problems, in: Beak trimming handbook for egg producers: best practices for minimising cannibalism in poultry, pp. 1-5. (Collingwood Victoria, Australia, CSIRO Publishing)

GROOTHUIS, T.G.G., MULLER, W., VON ENGELHARDT, N., CARERE, C. and EISING, C. (2005) Maternal hormones as a tool to adjust offspring phenotype in avian species. Neuroscience and Biobehavioral Reviews 29: 329-352.

GRUSS, M. and BRAUN, K. (1997) Distinct activation of monoaminergic pathways in chick brain in relation to auditory imprinting and stressful situations: A microdialysis study. Neuroscience 76: 891-899.

HARLANDER-MATAUSCHEK, A., BENDA, I., LAVETTI, C., DJUKIC, M. and BESSEI, W. (2007) The relative preferences for wood shavings or feathers in high and low feather pecking birds. Applied Animal Behaviour Science 107: 78-87.

HARLANDER-MATAUSCHEK, A. and HÄUSLER, K. (2009) Understanding feather eating behaviour in laying hens. Applied Animal Behaviour Science 117: 35-41.

HARLANDER-MATAUSCHEK, A., PIEPHO, H.P. and BESSEI, W. (2006) The effect of feather eating on feed passage in laying hens. Poultry Science 85: 21-25.

HEMSWORTH, P.H. and BARNETT, J.L. (1989) Relationships between fear of humans, productivity and cage position of laying hens. British Poultry Science 30: 505-518.

HETLAND, H., CHOCT, M. and SVIHUS, B. (2004) Role of insoluble non-starch polysaccharides in poultry nutrition. World's Poultry Science Journal 60: 415-422.

HOCKING, P.M., CHANNING, C.E., WADDINGTON, D. and JONES, R.B. (2001) Age-related changes in fear, sociality and pecking behaviours in two strains of laying hen. British Poultry Science 42: 414-423.

HUBER-EICHER, B. and WECHSLER, B. (1997) Feather pecking in domestic chicks: its relation to dustbathing and foraging. Animal Behaviour 54: 757-768.

HUGHES, A.L. and BUITENHUIS, A.J. (2010) Reduced variance of gene expression at numerous loci in a population of chickens selected for high feather pecking. Poultry Science 89: 1858-1869.

HUGHES, B.O. (1973) The effect of implanted gonadal hormones on feather pecking and cannibalism in pullets. British Poultry Science 14: 341-348.

HUGHES, B.O. and DUNCAN, I.J.H. (1972) The influence of strain and environmental factors upon feather pecking and cannibalism in fowls. British Poultry Science 13: 525-547.

HUGHES, B.O. and WHITEHEAD, C.C. (1974) Sodium deprivation, feather pecking and activity in laying hens. British Poultry Science 15: 435-439. 
JANCZAK, A.M., TORJESEN, P., PALME, R. and BAKKEN, M. (2007) Effects of stress in hens on the behaviour of their offspring. Applied Animal Behaviour Science 107: 66-77.

JENSEN, P., KEELING, L., SCHUTZ, K., ANDERSSON, L., MORMEDE, P., BRANDSTROM, H., FORKMAN, B., KERJE, S., FREDRIKSSON, R. and OHLSSON, C. (2005) Feather pecking in chickens is genetically related to behavioural and developmental traits. Physiology \& Behavior 86: 52-60.

JOHNSEN, P.F., VESTERGAARD, K.S. and NORGAARD NIELSEN, G. (1998) Influence of early rearing conditions on the development of feather pecking and cannibalism in domestic fowl. Applied Animal Behaviour Science 60: 25-41.

JONES, R.B. (1996) Fear and adaptability in poultry: insights, implications and imperatives. World's Poultry Science Journal 52: 131-174.

JONES, R.B., BLOKHUIS, H.J. and BEUVING, G. (1995) Open-field and tonic immobility responses in domestic chicks of two genetic lines differing in their propensity to feather peck. British Poultry Science 36: 525-530.

KJAER, J.B. and GUÉMENÉ, D. (2009) Adrenal reactivity in lines of domestic fowl selected on feather pecking behavior. Physiology \& Behavior 96: 370-373.

KJAER, J.B., HJARVARD, B.M., JENSEN, K.H., HANSEN-MOLLER, J. and NAESBYE LARSEN, O. (2004) Effects of haloperidol, a dopamine D2 receptor antagonist, on feather pecking behaviour in laying hens. Applied Animal Behaviour Science 86: 77-91.

KJAER, J.B. and JORGENSEN, H. (2011) Heart rate variability in domestic chicken lines genetically selected on feather pecking behavior. Genes Brain and Behavior 10: 747-755.

KJAER, J.B., SØRENSEN, P. and SU, G. (2001) Divergent selection on feather pecking behaviour in laying hens (Gallus gallus domesticus). Applied Animal Behaviour Science 71: 229-239.

KORTE, S.M. (2001) Corticosteroids in relation to fear, anxiety and psychopathology. Neuroscience \& Biobehavioral Reviews 25: 117-142.

KORTE, S.M., BEUVING, G., RUESINK, W. and BLOKHUIS, H.J. (1997) Plasma catecholamine and corticosterone levels during manual restraint in chicks from a high and low feather pecking line of laying hens. Physiology \& Behavior 62: 437-441.

KORTE, S.M., RUESINK, W. and BLOKHUIS, H.J. (1999) Heart rate variability during manual restraint in chicks from high- and low-feather pecking lines of laying hens. Physiology \& Behavior 65: 649-652.

LAMBTON, S.L., KNOWLES, T.G., YORKE, C. and NICOL, C.J. (2007) Gentle and severe feather pecking: one problem or two? Proceedings of the 41st International Congress of the ISAE, Merida. Mexico, pp. 48

LEONARD, M.L., HORN, A.G. and FAIRFULL, R.W. (1995) Correlates and consequences of allopecking in White Leghorn chickens. Applied Animal Behaviour Science 43: 17-26.

MAHBOUB, H.D.H., MÜLLER, J. and VON BORELL, E. (2004) Outdoor use, tonic immobility, heterophil/lymphocyte ration and feather condition in free-range laying hens of different genotype. British Poultry Science 45: 738-744.

MCADIE, T.M. and KEELING, L.J. (2002) The social transmission of feather pecking in laying hens: effects of environment and age. Applied Animal Behaviour Science 75: 147-159.

MCADIE, T.M., KEELING, L.J., BLOKHUIS, H.J. and JONES, R.B. (2005) Reduction in feather pecking and improvement of feather condition with the presentation of a string device to chickens. Applied Animal Behaviour Science 93: 67-80.

MCKEEGAN, D.E.F. and SAVORY, C.J. (1999) Feather eating in layer pullets and its possible role in the aetiology of feather pecking damage. Applied Animal Behaviour Science 65: 73-85.

METZGER, M., TOLEDO, C. and BRAUN, K. (2002) Serotonergic innervation of the telencephalon in the domestic chick. Brain Research Bulletin 57: 547-551.

NEWBERRY, R.C. (2004) Cannibalism, in: PERRY, G.C. (Ed.) Welfare of the laying hen, pp. 239-258 (Wallingford, United Kingdom, CABI Publishing).

NEWBERRY, R.C., KEELING, L.J., ESTEVEZ, I. and BILCIK, B. (2007) Behaviour when young as a predictor of severe feather pecking in adult laying hens: The redirected foraging hypothesis revisited. Applied Animal Behaviour Science 107: 262-274.

NICOL, C.J., LINDBERG, A.C., PHILLIPS, A.J., POPE, S.J., WILKINS, L.J. and GREEN, L.E. (2001) Influence of prior exposure to wood shavings on feather pecking, dustbathing and foraging in adult laying hens. Applied Animal Behaviour Science 73: 141-155.

NRC (1994) Nutrient Requirements of Poultry. 9th rev. ed. Natl. Acad. Press, Washington, DC.

RAMADAN, S.G.A. and VON BORELL, E. (2008) Role of loose feathers on the development of feather pecking in laying hens. British Poultry Science 49: 250 - 256.

RIEDSTRA, B. and GROOTHUIS, T.G.G. (2002) Early feather pecking as a form of social exploration: the effect of group stability on feather pecking and tonic immobility in domestic chicks. Applied Animal Behaviour Science 77: 127-138. 
RODENBURG, T.B., BOLHUIS, J.E., KOOPMANSCHAP, R.E., ELLEN, E.D. and DECUYPERE, E. (2009a) Maternal care and selection for low mortality affect post-stress corticosterone and peripheral serotonin in laying hens. Physiology \& Behavior 98: 519-523.

RODENBURG, T.B., BUITENHUIS, A.J., ASK, B., UITDEHAAG, K.A., KOENE, P., VAN DER POEL, J.J., VAN ARENDONK, J.A.M. and BOVENHUIS, H. (2004a) Genetic and phenotypic correlations between feather pecking and open-field response in laying hens at two different ages. Behavior Genetics 34: 407-415.

RODENBURG, T.B., DE HAAS, E.N., NIELSEN, B.L. and BUITENHUIS, A.J. (2010) Fearfulness and feather damage in laying hens divergently selected for high and low feather pecking. Applied Animal Behaviour Science 128: 91-96.

RODENBURG, T.B., DE REU, K. and TUYTTENS, F.A.M. (2012) Performance, welfare, health and hygiene of laying hens in non-cage systems in comparison with cage systems, in: SANDILANDS, V. \& HOCKING, P. (Eds) Alternative Systems for Poultry - Health, Welfare and Productivity, pp. 210-224 (Glasgow, United Kingdom)

RODENBURG, T.B. and KOENE, P. (2003) Comparison of individual and social feather pecking tests in two lines of laying hens at ten different ages. Applied Animal Behaviour Science 81: 133-148.

RODENBURG, T.B., KOMEN, H., ELLEN, E.D., UITDEHAAG, K.A. and VAN ARENDONK, J.A.M. (2008) Selection method and early-life history affect behavioural development, feather pecking and cannibalism in laying hens: A review. Applied Animal Behaviour Science 110: 217-228.

RODENBURG, T.B., UITDEHAAG, K.A., ELLEN, E.D. and KOMEN, J. (2009b) The effects of selection on low mortality and brooding by a mother hen on open-field response, feather pecking and cannibalism in laying hens. Animal Welfare 18: 427-432.

RODENBURG, T.B., VAN HIERDEN, Y.M., BUITENHUIS, A.J., RIEDSTRA, B., KOENE, P., KORTE, S.M., VAN DER POEL, J.J., GROOTHUIS, T.G.G. and BLOKHUIS, H.J. (2004b) Feather pecking in laying hens: new insights and directions for research? Applied Animal Behaviour Science 86: 291-298.

SAVORY, C.J. (1980) Meal occurrence in Japanese quail in relation to particle size and nutrient density. Animal Behaviour 28: 160-171.

SAVORY, C.J. (1995) Feather pecking and cannibalism. World's Poultry Science Journal 51: 215-219.

SCHAIBLE, P.J., DAVIDSON, J.A. and BANDEMER, S.L. (1947) Cannibalism and feather pecking in chicks as influenced by certain changes in a specific ration. Poultry Science 26: 651-656.

SCHWABL, H. (1993) Yolk is a source of maternal testosterone for developing birds. Proceedings Of The National Academy Of Sciences Of The United States Of America 90: 11446-11450.

SUNDE, M.L. (1972) Zinc requirement for normal feathering of commercial Leghorn-type pullets. Poultry Science 51: 1316-1322.

UITDEHAAG, K., KOMEN, H., RODENBURG, T.B., KEMP, B. and VAN ARENDONK, J. (2008a) The novel object test as predictor of feather damage in cage-housed Rhode Island Red and White Leghorn laying hens. Applied Animal Behaviour Science 109: 292-305.

UITDEHAAG, K.A., RODENBURG, T.B., BOLHUIS, J.E., DECUYPERE, E. and KOMEN, H. (2009) Mixed housing of different genetic lines of laying hens negatively affects feather pecking and fear related behaviour. Applied Animal Behaviour Science 116: 58-66.

UITDEHAAG, K.A., RODENBURG, T.B., KOMEN, H., KEMP, B. and VAN ARENDONK, J.A.M. (2008b) The association of response to a novel object with subsequent performance and feather damage in adult, cage-housed, pure-bred Rhode Island Red laying hens. Poultry Science 87: 2486-2492.

VAN DER LEE, A.G., HEMKE, G. and KWAKKEL, R.P. (2001) Low density diets improve plumage condition in non-debeaked layers. Proceedings of the $13^{\text {th }}$ European Symposium on Poultry Nutrition, Blankenbergen, Belgium, pp. 244-245

VAN HIERDEN, Y.M., DE BOER, S.F., KOOLHAAS, J.M. and KORTE, S.M. (2004a) The control of feather pecking by serotonin. Behavioral Neuroscience 118: 575-583.

VAN HIERDEN, Y.M., KOOLHAAS, J.M. and KORTE, S.M. (2004b) Chronic increase of dietary -tryptophan decreases gentle feather pecking behaviour. Applied Animal Behaviour Science 89: 71-84.

VAN HIERDEN, Y.M., KOOLHAAS, J.M., KOST'AL, L.U., VYBOH, P., SEDLACKOVA, M., RAJMAN, M., JURANI, M. and MECHIEL KORTE, S. (2005) Chicks from a high and low feather pecking line of laying hens differ in apomorphine sensitivity. Physiology \& Behavior 84: 471-477.

VAN HIERDEN, Y.M., KORTE, S.M., RUESINK, E.W., VAN REENEN, C.G., ENGEL, B., KOOLHAAS, J.M. and BLOKHUIS, H.J. (2002a) The development of feather pecking behaviour and targeting of pecking in chicks from a high and low feather pecking line of laying hens. Applied Animal Behaviour Science 77: 183-196.

VAN HIERDEN, Y.M., KORTE, S.M., RUESINK, E.W., VAN REENEN, C.G., ENGEL, B., KORTEBOUWS, G.A.H., KOOLHAAS, J.M. and BLOKHUIS, H.J. (2002b) Adrenocortical reactivity and central serotonin and dopamine turnover in young chicks from a high and low feather-pecking line of laying hens. Physiology \& Behavior 75: 653-659. 
VAN HORNE, P.L.M. and ACHTERBOSCH, T.J. (2008) Animal welfare in poultry production systems: impact of EU standards on world trade. World's Poultry Science Journal 64: 40-52.

VAN KRIMPEN, M.M., BINNENDIJK, G.P. and VAN DIEPEN, J.T.M. (2012) Effect of diluted practical diets on plumage condition, behaviour and performance of rearing and laying hens. Report 534 Wageningen UR Livestock Research Lelystad The Netherlands. pp. 1-47.

VAN KRIMPEN, M.M., DE BRUIN, W.W., DE VEER, R. and BINNENDIJK, G.P. (2010) Effect of diluted NSP-high diets under feather pecking prone conditions on the development of feather damage and performance of rearing and laying hens. Report 420. Wageningen UR Livestock Research, Lelystad, The Netherlands. pp. 1-46.

VAN KRIMPEN, M.M., KWAKKEL, R.P., ANDRÉ, G., VAN DER PEET-SCHWERING, C.M.C., DEN HARTOG, L.A. and VERSTEGEN, M.W.A. (2007) Effect of nutrient dilution on feed intake, eating time and performance of hens in early lay. British Poultry Science 48: 389-398.

VAN KRIMPEN, M.M., KWAKKEL, R.P., REUVEKAMP, B.F.J., VAN DER PEET-SCHWERING, C. M.C., DEN HARTOG, L.A. and VERSTEGEN, M.W.A. (2005) Impact of feeding management on feather pecking in laying hens. World's Poultry Science Journal 61: 663-685.

VAN KRIMPEN, M.M., KWAKKEL, R.P., VAN DER PEET-SCHWERING, C.M.C., DEN HARTOG, L. A. and VERSTEGEN, M.W.A. (2009) Effects of nutrient dilution and nonstarch polysaccharide concentration in rearing and laying diets on eating behavior and feather damage of rearing and laying hens. Poultry Science 88: 759-773.

VAN KRIMPEN, M.M., KWAKKEL, R.P., VAN DER PEET-SCHWERING, C.M.C., DEN HARTOG, L. A. and VERSTEGEN, M.W.A. (2011) Effects of dietary energy concentration, nonstarch polysaccharide concentration, and particle sizes of nonstarch polysaccharides on digesta mean retention time and gut development in laying hens. British Poultry Science 52: 730-741.

VESTERGAARD, K.S., KRUIJT, J.P. and HOGAN, J.A. (1993) Feather pecking and chronic fear in groups of red junglefowl: their relations to dustbathing, rearing environment and social status. Animal Behaviour $\mathbf{4 5}$ : 1127-1140.

VESTERGAARD, K.S. and LISBORG, L. (1993) A model of feather pecking development which relates to dustbathing in the fowl. Behaviour 126: 291-308.

VON ENGELHARDT, N. and GROOTHUIS, T.G.G. (2011) Maternal hormones in avian eggs, in: NORRIS, D.O. \& LOPEZ, K.H. (Eds) Hormones and Reproduction of Vertebrates, Volume 4: Birds, pp. 91-127 (Academic Press).

WEBSTER, A.B. (1995) Immediate and subsequent effects of a short fast on the behavior of laying hens. Applied Animal Behaviour Science 45: 255-266. 
374 World's Poultry Science Journal, Vol. 69, June 2013 